\title{
PENINGKATAN HASIL BELAJAR SISWA MENGGUNAKAN MEDIA PERMAINAN ULAR TANGGA PADA MATA PELAJARAN IPS DI KELAS IV SEKOLAH DASAR NEGERI 02 LENGKENAT
}

\author{
Akhmad Hasan ${ }^{1}$, Purniadi Putra ${ }^{2}$ \\ Institut Agama Islam Sultan Muhammad Syafiuddin Sambas
}

INFO ARTIKEL

Diterima: $16-12-2020$

Disetujui: 2-2-2020

\section{Kata Kunci: Hasil}

Belajar, Media

Permainan Ular

Tangga

\begin{abstract}
Abstrak: Tujuan dalam penelitian ini adalah mendeskripsikan peningkatan hasil belajar siswa setelah menggunakan Media Permainan Ular Tangga pada Mata Pelajaran IPS di kelas IV Sekolah Dasar Negeri 02 Lengkenat Tahun Pelajaran 2019/2020. Pendekatan dalam penelitian ini adalah kualitatif bentuk penelitian Tindakan Kelas. Hasil penelitian diperoleh Media Permainan Ular Tangga dapat meningkatkan hasil belajar siswa pada mata pelajaran IPS dengan kategori sangat baik dan siswa berperan aktif, peningkatan hasil belajar siswa dengan Media Permainan Ular Tangga pada siklus I diperoleh hasil belajar siswa rata-rata sebesar $68,8 \%$ dan meningkat pada siklus II mencapai $82 \%$ sehingga terjadi peningkatan hasil belajar siswa sebesar 13,2\%. Tingkat ketuntasan klasikal pada siklus I sebesar $80 \%$ dan tingkat ketuntasan klasikal pada siklus II mencapai 96\%. Sehingga ketuntasan hasil belajar siswa pada siklus II dinyatakan berhasil karena dari data yang diperoleh telah mencapai ketuntasan sedangkan respon siswa melalui hasil wawancara guru dan siswa menunjukkan respon positif terhadap Media Permainan Ular Tangga.
\end{abstract}

\begin{abstract}
The purpose of this study was to describe the increase in student learning outcomes after using the Snake and Ladder Game Media in Social Studies Subjects in class IV of 02 Lengkenat Public Elementary School in the 2019/2020 Academic Year. The approach in this research is a qualitative form of classroom action research. The research results obtained that the Snake and Ladder Game Media can improve student learning outcomes in social studies subjects with a very good category and students play an active role, increase student learning outcomes with the Snake and Ladder Game Media in cycle I obtained an average student learning outcomes of $68.8 \%$ and increased in cycle II reached $82 \%$ so that there was an increase in student learning outcomes by $13.2 \%$. The classical completeness level in the first cycle was $80 \%$ and the classical completeness level in the second cycle was $96 \%$. So that the completeness of student learning outcomes in cycle II was declared successful because the data obtained had reached completeness, while student responses through the results of teacher and student interviews showed a positive response to the Snake and Ladder Game Media.
\end{abstract}

Alamat Korespondensi
Nama : Purniadi Putra
Instansil : Institut Agama Islam Sultan Muhammad Syafiuddin Sambas
Alamat instansi : Jalan Raya Sejangkung, Kawasan Pendidikan Sebayan, Sambas Kalimantan Barat.

Pendidikan merupakan proses perubahan sikap dan tingkah laku dalam usaha mendewasakan manusia melalui pengajaran dan pelatihan dengan mengembangkan potensi yang dimiliki. Melalui pendidikan berbagai ilmu pengetahuan yang berguna dalam kehidupan dapat diperoleh. Secara etimologi pendidikan berasal dari kata "didik", kemudian kata itu mendapat awalan me sehingga menjadi "mendidik", artinya memelihara dan memberi latihan. Dalam memelihara dan memberi latihan diperlukan adanya ajaran, tuntunan, dan pimpinan mengenai akhlak dan kecerdasan pikiran (Syah, 2010: 10). Tujuan pendidikan adalah seperangkat hasil pendidikan yang tercapai oleh peserta didik setelah diselenggarakannya kegiatan pendidikan. Seluruh kegiatan pendidikan, yakni bimbingan pengajaran atau latihan 
diarahkan untuk mencapai tujuan pendidikan. artinis mengatakan bahwa, metode pembelajaran merupakan cara melakukan atau menyajikan, menguraikan, member contoh, dan memberi latihan isi pelajaran kepada siswa untuk mencapai tujuan tertentu. (Putra, 2017). Sedangkan Soelaiman Joesoef, memberikan penafsikan, bahwa metode adalah suatu kerangka kerja dan dasar-dasar pemikiran digunakannya cara-cara yang khusus. Metode merupakan jalan menuju suatu tujuanTujuan belajar adalah sejumlah hasil belajar yang menunjukkan bahwa siswa telah melakukan tugas belajar, yang umumnya meliputi pengetahuan, keterampilan dan sikap-sikap yang baru, yang diharapkan tercapai oleh siswa setelah berlangsungnya proses belajar. Ilmu Pengetahuan Sosial (IPS) merupakan salah satu mata pelajaran yang disusun dalam Kurikulum Tingkat Satuan Pendidikan (KTSP) dan diberikan mulai dari SD hingga SMA.

Menurut Afandi (Mar'atusholihah, Priyanto, \& Tika Damayani, 2019) media yang sesuai dengan kondisi yang ada yaitu media permainan (permainan edukatif), hal ini sesuai karakteristik peserta didik sekolah dasar yang senang bermain. Media pembelajaran ular tangga merupakan media pembelajaran yang dikembangkan berdasarkan permainan tradisional, permainan ular tangga disesuaikan dengan karakteristik peserta didik dengan tujuan untuk mencapai tujuan pembelajaran sebagai pengantar informasi bagi peserta didik.

Nachiappan et,al (Firman, Amiruddin Ridwan, 2020) yang hasilnya menunjukkan bahwa terdapat peningkatan pengetahuan setelah intervensi dengan media permainan ular tangga. Peningkatan pengetahuan setelah dilakukan pengukuran berulang penulis mengasumsikan bahwa kemampuan seseorang mengingat dan mengolah pesan yang telah didapat sebelumnya.

Berdasarkan struktur KTSP, bahan kajian IPS meliputi kemampuan memahami seperangkat fakta, konsep, dan generalisasi tentang sistem sosial dan budaya, manusia, lingkungan, perilaku ekonomi dan kesejahteraan, waktu, keberlanjutan dan perubahan serta sistem berbangsa dan bernegara. Berdasarkan hasil praobservasi yang dilakukan pada tanggal 22 Februari 2019 di Sekolah Dasar Negeri 02 Lengkenat, hasil belajar yang diperoleh siswa masih banyak yang belum mencapai ketuntasan minimal (KKM) yaitu 65. Hal ini terbukti dari hasil ulangan IPS yang penulis peroleh dari guru mata pelajaran IPS, menunjukkan bahwa dari 25 siswa kelas IV Sekolah Dasar Negeri 02 Lengkenat hanya 5 siswa atau $20 \%$ yang telah mencapai ketuntasan. Sedangkan 20 siswa atau $80 \%$ belum mencapai batas ketuntasan yang sudah ditentukan. Secara umum masalah yang terjadi di Sekolah Dasar Negeri 02 Lengkenat pada Kelas IV adalah daya ingat dan cara berpikir siswa masih sangat rendah. Berdasarkan observasi dan wawancara singkat dengan guru kelas, hal ini disebabkan karena keterlibatan siswa secara langsung dalam pembelajaran sangat minim sehingga siswa tidak memahami materi yang diajarkan. Berdasarkan pemaparan di atas, peneliti tertarik untuk meneliti tentang penggunaan media permainan ular tangga karena permainan ini efektif digunakan untuk melatih cara berpikir siswa. Permainan ular tangga menurut Ratnaningsih (2014: 57) adalah jenis permainan papan yang memiliki petak berjumlah 50, terbagi dalam 10 baris dan $5 \mathrm{kolom}$, dan dimainkan dengan menggunakan dadu dan bidak sesuai jumlah pemain. Dengan menggunakan media permainan ular tangga dalam proses pembelajaran terutama pelajaran IPS dapat meningkatkan hasil belajar siswa. Oleh karena itu peneliti meneliti tentang "Peningkatan Hasil Belajar Siswa menggunakan Media Permainan Ular Tangga pada Mata Pelajaran IPS di Kelas IV Sekolah Dasar Negeri 02 Lengkenat Tahun Pelajaran 2019/2020".

\section{METODE}

Pendekatan penelitian ini menggunakan pendekatan penelitian kualitatif. Secara umum metode merupakan suatu cara atau prosedur yang dipakai untuk mencapai tujuan tertentu. Dalam penelitian ini, peneliti menggunakan metode deskriptif dengan pendekatan kualitatif. Bentuk penelitian yang digunakan adalah Penelitian Tindakan Kelas (Class Room Action Research). Menurut Arikunto (2010: 16) PTK terdiri atas empat rangkaian kegiatan yang dilakukan dalam siklus berulang, yaitu perencanaan (planning), Pelaksanaan (Acting), pengamatan (Observasing) dan Refleksi (Reflecting). Penelitian ini dilaksanakan di kelas IV Sekolah Dasar Negeri 02 Lengkenat, jalan Sintang - Pontianak, Desa Lengkenat, Kecamatan Sepauk, Kabupaten Sintang. Subjek penelitian ini adalah siswa kelas IV Sekolah Dasar Negeri No 02 Lengkenat yang terdiri dari 25 siswa, laki- laki berjumlah 12 orang sedangkan yang 
perempuan berjumlah 13 orang. dalam penelitian ini yang menjadi objek penelitian adalah hasil belajar siswa dalam pembelajaran IPS dengan menggunakan media pembelajaran dengan pendekatan berpikir dan berbasis masalah yaitu media permainan ular tangga.

Dalam penelitian ini yang menjadi objek penelitian adalahhasil belajar siswa dalam pembelajaran IPS dengan menggunakan media pembelajaran dengan pendekatan berpikir dan berbasis masalah yaitu media permainan ular tangga. Data merupakan bukti, fakta, atau informasi akurat yang digunakan sebagai bahan untuk memecahkan suatu permasalahan. Menurut Arikunto, dkk (2013: 266), "Data yang diungkapkan dalam penelitian dapat dibedakan menjadi tiga jenis, yaitu: Fakta, pendapat, dan kemampuan". Sumber data yang digunakan ada dua yaitu sumber data primer dan sumber data sekunder. Teknik pengumpulan data yang digunakan dalam penelitian ini yaitu teknik observasi langsung, teknik komunikasi langsung, teknik pengukuran dan teknik dokumentasi serta alat pengumpulan data pada penelitian ini yaitu lember observasi, lembar wawancara, lembar tes dan dokumentasi. Sugiyono (2013: 330) menyatakan, Triangulasi diartikan sebagai teknik pengumpulan data yang bersifat menggabungkan dari berbagai teknik pengumpulan data yang telah ada.Dalam penelitian ini peneliti melakukan keabsahan data agar data-data yang dikumpulkan menjadi data- data yang valid. Menurut Yanto (2013: 67) teknik analisis data merupakan lanjutan dari tahap pengumpulan data, lakngkah-langkah teknik analisis data pada penelitian ini yaitu pengumpulan data, reduksi data, penyajian data dan kesimpulan/verifikasi. Peyajian data merupakan salah satu kegiatan dalam pembuatan laporan hasil penelitian yang telah dilakukan agar dapat dipahami dan dianalisis sesuai dengan tujuan yang diinginkan,

a. Analisis data observasi untuk menyajikan data hasil observasi menggunakan tanda centang/ checklist $(\sqrt{ })$ pada kolom ya atau tidak, sesuai hasil observasi dengan menghitung persentase dengan menggunakan rumus:

$\mathrm{P}=\frac{F}{N} \times 100 \%$

Keterangan:

$\mathrm{P}=$ angka persentase

$\mathrm{F}=$ frekuensi yang sedang dicari

$\mathrm{N}=$ Number of Casse (jumlah frekuensi),

b. Tes untuk menghitung dan menyajikan skor tes menggunakan Media Permainan Ular Tangga pada setiap siswa menggunakan rumus :

$\mathrm{S}=\frac{B}{N} \times 100 \%$

Keterangan

B : jumlah jawaban benar

$\mathrm{N}$ : jumlah soal (skala $0-100)$

Sedangkan untuk menghitung rata-rata menggunakan rumus :

$\mathrm{X}=\frac{\sum X}{n}$

Keterangan:

$\mathrm{X}$ : rata-rata

$\mathrm{n}$ : banyak perserta

$\sum \mathrm{x}$ : jumlah semua skor.

\section{HASIL}

Penggunaan Media Permainan Ular Tangga pada Mata Pelajaran IPS Di Kelas IV Sekolah Dasar Negeri 02 Lengkenat Tahun Pelajaran 2019/2020. Media permainan ular tangga merupakan suatu media pembelajaran yang digunakan sebagai alat bantu mempermudah dalam menjelaskan materi pembelajaran dan sangat cocok diterapkan khususnya di sekolah dasar pada materi kenampakan alam. Berdasarkan hasil penelitian dari alat pengumpulan data berupa lembar observasi siswa pada siklus I dan siklus II di kelas IV Sekolah Dasar Negeri 02 Lengkenat terlihat peningkatan pada hasil dan sikap siswa dalam pembelajaran dengan media permainan ular tangga dari segi perhatian, keaktifan dan kerjasama pada saat berlangsung penggunaan media permainan ular tangga. Dari hasil wawancara guru dan siswa diperoleh respon yang positif setelah penggunaan media permainan ular tangga hal ini dapat dibuktikan 
dengan adanya hasil dokumentasi yang menunjukkan bahwa dengan adanya penggunaan media permainan ular tangga dalam pembelajaran mampu melatih siswa untuk menunjukkan sikap perhatiaan, keaktifan dan kerjasama dalam kelas terhadap materi pelajaran IPS. Sehingga mampu memperoleh hasil belajar yang memuaskan. Peningkatan Hasil Belajar Siswa Menggunakan Media Permainan Ular Tangga pada Mata Pelajaran IPS Di Kelas IV Sekolah Dasar Negeri 02 Lengkenat Tahun Pelajaran 2019/2020. Berdasarkan hasil yang diperoleh siswa pada siklus I diperoleh dari 25 siswa yang mengikuti tes hanya 20 siswa yang tuntas dan 5 siswa yang tidak tuntas dikarenakan Siswa kurang fokus pada saat proses pembelajaran, siswa belum terlalu memahami dan masih merasa bingung dengan media permainan ular tangga serta nilai yang diperoleh siswa masih ada dibawah nilai KKM. Rata-rata nilai sebesar 68,8 dengan ketuntasan klasikal 80\%.

Pada tahap ini belum mencapai ketuntasan klasikal hal ini terjadi karena siswa belum memahami dan mengerti serta siswa masih terlihat bingung dengan media permainan ular tangga karena baru pertama kalinya media ini digunakan di sekolah mereka, dengan demikan dilanjutkan ke tahap berikutnya yaitu siklus II dengan harapan hasil belajar siswa yang diperoleh dapat mencapai ketuntasan. Pada siklus II hasil belajar siswa meningkat dari 25 siswa yang mengikuti tes, siswa yang tuntas sebanyak 24 siswa dan 1 orang siswa tidak tuntas dikarenakan pada saat proses pembelajaran berlangsung, masih ada beberapa siswa yang ribut dan tidak mengikuti pembelajaran dengan baik, nilai rata-rata 82 dan ketuntasan klasikal 96\%.

Menurut Pramita Amilia dan Agustini Rudiana (Ninkeula, Filindity, \& Dulanlebit, 2019) ular tangga merupakan salah satu bentuk permainan yang merakyat dan digemari dari usia anakanak, remaja, bahkan dewasa, selain itu media permainan ular tangga sangat efektif dalam proses pembelajaran, ular tangga dalam penelitian ini didesain menggunakan kartu yang berisi soal materi struktur atom serta menampilkan gambar-gambar yang berhubungan dengan kimia sehingga terlihat lebih menarik Penelitian.

Berdasarkan hasil belajar siswa yang diperoleh dari siklus I dan siklus II mengalami peningkatan sebesar $16 \%$. Sehingga ketuntasan hasil belajar pada siklus II dinyatakan berhasil Karena dari data yang diperoleh telah mencapai ketuntasan.Respon Siswa Menggunakan Media Permainan Ular Tangga pada Mata Pelajaran IPS Di Kelas IV Sekolah Dasar Negeri 02 Lengkenat Tahun Pelajaran 2019/2020. Dari hasil data wawancara untuk siswa berdasarkan item pertanyaan siswa mengatakan bahwa media permainan ular tangga belum pernah diterapkan sebelumnya, dengan demikian siswa merasa sangan senang dan bahagia terhadap media permainan ular tangga karena selain menarik, melatih siswa untuk fokus dalam belajar, dalam pembelajaran materi yang diberikan oleh guru mudah dimengerti oleh siswa sehingga hasil belajar yang mereka dapatkan meningkat. Wawancara ini dilakukan dengan 3 orang siswa, satu orang siswa dengan nilai tertinggi, satu orang siswa dengan nilai sedang dan satu orang siswa yang memperoleh nilai rendah hal ini dilakukan untuk melihat respon siswa setelah penerapan media permainan ular tangga. Sedangkan hasil wawancara peneliti dengan guru mata pelajaran IPS tentang respon penggunaan media permainan ular tangga di kelas IV Sekolah Dasar Negeri 02 Lengkenat mendapat respon yang positif salah satunya yaitu guru mata pelajaran IPS mengatakan bahwa dengan adanya media permainan ular tangga dalam proses pembelajaran bisa meningkatkan hasil belajar siswa dan bisa membuat siswa lebih kreaktif dan fokus dalam mengikuti proses pembelajaran, maka dapat peneliti simpulkan bahwa media permainan ular tangga sangat cocok digunakan dalam proses pembelajaran untuk meningkatkan hasil belajar siswa.

\section{SIMPULAN DAN SARAN}

Penggunaan Media Permainan Ular Tangga pada Mata Pelajaran IPS di kelas IV Sekolah Dasar Negeri 02 Lengkenat Tahun Pelajaran 2019/2020. Dapat meningkatan hasil belajar IPS pada siswa. Siswa mengikuti pembelajaran dengan tertib, siswa memperhatikan dengan teliti, siswa aktif bertanya kepada guru, serta pada saat berlangsungnya penggunaan media permainan ular tangga siswa berperan aktif menjawab pertanyaan dengan baik. Hasil observasi siswa pada siklus I menunjukkan hasil dari 10 aspek yang diamati 8 aspek yang bisa dilaksanakan sementara 2 aspek tidak dapat dilaksanakan, dengan presentase klasikal 80\% dan Hasil dari 10 
aspek menunjukkan 10 aspek dapat teramati. Pada siklus II diperoleh hasil observasi dengan presentase klasikal $100 \%$ dari hasil observasi siklus II dapat diketahui bahwa hasil observasi siswa siklus II meningkat dari hasil observasi siklus I, sebesar 20\%. Hasil observasi guru pada siklus I diketahui hasil observasi guru siklus I diperoleh hasil dari 10 aspek observasi, yang teramati adalah 7 aspek dan yang tidak teramati adalah 3 aspek dengan kentuntasan klasikal $70 \%$ dan hasil observasi pada tahap siklus II berlangsung dengan sangat baik hal tersebut dapat dibuktikan dengan hasil observasi yaitu dari 10 aspek yang teramati ketuntasan klasikal 100\% dari hasil observasi guru siklus II dapat diketahui bahwa hasil observasi guru siklus II meningkat dari hasil observasi siklus I, sebesar 30\%. Sehingga hasil belajar yang diperoleh siswa baik.Media ini dapat meningkatkan hasil belajar siswa apabila dilakukan sesuai dengan langkah-langkah media permainan ular tangga dan mempermudahkan guru dalam menyampaikan materi. Peningkatan Hasil Belajar Siswa Menggunakan Media Permainan Ular Tangga pada Mata Pelajaran IPS Di Kelas IV Sekolah Dasar Negeri 02 Lengkenat Tahun Pelajaran 2019/2020. Hasil penelitian menunjukkan adanya peningkatan hasil belajar siswa pada setiap siklusnya, pada siklus I nilai rata-rata siswa sebesar $68,8 \%$ dan meningkat pada siklus II mencapai $82 \%$ sehingga terjadi peningkatan hasil belajar sebesar $13.2 \%$.

Tingkat ketuntasan klasikal pada siklus I adalah $82 \%$ dari 25 orang siswa yang tuntas 24 dan 5 orang tidak tuntas.Pada siklus II sebanyak 24 siswa yang tuntas dan 1 orang yang tidak tuntas serta ketuntasan klasikal mencapai 96\%. Berdasarkan hasil belajar siswa yang diperoleh dari siklus I dan siklus II mengalami peningkatan sebesar 16\%. Dengan demikian penggunaan media permainan ular tangga sudah mengalami peningkatan dan indikator siswa telah mencapai KKM. Respon Siswa Menggunakan Media Permainan Ular Tangga pada Mata Pelajaran IPS Di Kelas IV Sekolah Dasar Negeri 02 Lengkenat Tahun Pelajaran 2019/2020. Hasil dari respon siswa terhadap media permainan ular tangga sangat baik dan siswa merasa sangat senang dan bahagia terhadap media permainan ular tangga karena selain menarik, melatih siswa untuk fokus dalam belajar, dalam pembelajaran materi yang diberikan oleh guru mudah dimengerti oleh siswa, sehingga hasil belajar yang mereka dapatkan meningkat. Sedangkan hasil wawancara peneliti dengan guru mata pelajaran IPS tentang respon penggunaan media permainan ular tangga di kelas IV Sekolah Dasar Negeri 02 Lengkenat mendapat respon yang positif salah satunya yaitu guru mata pelajaran IPS mengatakan bahwa dengan adanya media permainan ular tangga dalam proses pembelajaran bisa meningkatkan hasil belajar siswa dan bisa membuat siswa lebih kreaktif dan fokus dalam mengikuti proses pembelajara. Dilihat dari hasil wawancara guru dan siswa dapat disimpulkan dengan media permainan ular tangga dapat meningkatkan hasil belajar IPS pada siswa kelas IV SD Negeri 02 Lengkenat dengan diterapkan media ini dapat membuat siswa termotivasi untuk belajar sehingga mendapatkan hasil belajar yang memuaskan dan media ini melatih siswa untuk fokus dalam belajar sehingga dapat digunakan dalam pembelajaran khususnya IPS.

\section{DAFTAR RUJUKAN}

Arikunto, S. dkk. 2010. Penelitian Tindakan Kelas. Jakarta: PT Bumi Aksara.

Firman, Amiruddin Ridwan, D. I. (2020). Hasanuddin Journal of Public Health. HJPH, 1(1), 61-70.

Mar'atusholihah, H., Priyanto, W., \& Tika Damayani, A. (2019). Pengembangan Media Pembelajaran Tematik Ular Tangga Berbagai Pekerjaan. Jurnal Mimbar PGSD Undiksha, 7(3), 253-260.

Ninkeula, I., Filindity, Y. T., \& Dulanlebit, Y. H. (2019). Komparasi Media Pembelajaran Kokami Dan Media Ular Tangga Menggunakan Model Pembelajaran Langsung Pada Materi Struktur Atom Terhadap Hasil Belajar Siswa Kelas X SMA Negeri 5 Ambon. Molluca Journal of Chemistry Education (MJoCE), 9 (2), 70-77. https://doi.org/10.30598/mjocevol9iss2pp70-77

Putra, P. (2017). Hubungan Metode Bermain, Cerita, Dan Menyanyi (Bcm) Dengan Prestasi Belajar Siswa Sd Menurut Persepsi Mahasiswa Uin Maulana Malik Ibrahim Malang. MODELING: Jurnal Program Studi PGMI, 4(2), 147-161. 
KARANGAN: Jurnal Kependidikan, Pembelajaran, dan Pengembangan, Vol 03, No 01, Bulan Februari, Tahun 2021, Hal 15-20

Ratnaningsih. N. N. 2014. "Penggunaan Permainan Ular Tangga untuk Meningkatkan Motivasi Belajar IPS Kelas III A SDN Nogoporo". Skripsi. Sleman : Universitas Negeri Yogyakarta.

Sugiyono. 2013. Metode Penelitian Pendidikan Pendekatan Kuantitatif, Kualitatif, dan R\&D. Bandung: Alfabeta.

Syah, M. 2010. Psikologi Pendidikan Dengan Pendekatan Baru. Bandung: PT Remaja Rosdakarya.

Yanto, M. 2013. Jadi Guru yang Jago. Penelitian Tindakan Kelas. Yogyakarta: ANDI. 